\title{
ANALYSIS OF ANCIENT VENTILATION AND ILLUMINATION PRACTICES IN ANATOLIAN SELJUK AND OTTOMAN HOSPITALS AND SUGGESTIONS FOR THEIR CONSERVATION MEASURES
}

\author{
GÜLŞEN DİŞLI \\ Turkish Republic Prime Ministry Directorate General of Foundations, Department of Art \\ and Construction Works, Turkey.
}

\begin{abstract}
As one of the necessities of humanity, ventilation is closely linked to the heating and illumination of spaces, and spaces such as in hospitals were among the first to need appropriately clean air for the health conditions of both patients and workers. In the different regions of Anatolia, many historic hospitals were built during the Seljuk and Ottoman periods. The primary function of those buildings was to take care of patients, yet in time they needed to care for themselves: so much so that only eleven of them are intact today, and just one continues to be used for its original function. Hence, this article presents the key ventilation and illumination practices applied over the centuries in those existing hospitals located in different regions of Anatolia and built during the 13th and 18th centuries; it also shows their influence on the architecture of the buildings in order to raise awareness of these issues in respect of their conservation. The study examines foundation archives and literature on the historic hospitals, including in situ observations, with a special focus on their ancient ventilation and illumination practices. The analysis reveals the similarities in and differences between these practices in the Seljuk and Ottoman periods. In addition, it assesses the potential conservation measures of these ancient passive survivability means used in Anatolian historic hospitals. The major conclusion of the study is that ancient ventilation and illumination practices may provide for the sustainability of historic hospitals in the long term and may, with the correct conservation solutions, contribute to their longevity.

Keywords: Anatolia, conservation, functional systems, historic hospitals, illumination, Seljuk and Ottoman period, ventilation.
\end{abstract}

\section{INTRODUCTION}

In the Seljuk and Ottoman periods in Anatolia, there were many hospitals providing services to both inpatients and outpatients every day, with a considerable labour force, as clearly indicated in their endowment deeds. In those health institutions, the patients were treated without any fee for either health services or food and medicine [1-3]. Against this general background, this study examines aspects of the functional system of the Anatolian Seljuk and Ottoman period hospitals' history as one important perspective. Among those system aspects, it focuses on ventilation and illumination practices, as inevitable parts of health conditions, in order to explore the relationship between those systems and the architecture of the building itself. The network of functional systems, such as heating, refrigeration, drainage, ventilation and illumination, which are somehow connected to the building entity and to the urban planning in larger contexts, were hardly superficial; rather, they played a significant role in the longevity of the building itself, as well as in the services performed in it. Thus, the patients and workers of the hospitals, who in fact were unaware of those systems, were those mostly affected by the poor or high quality of ventilation and illumination of spaces inside the hospitals. 


\section{BACKGROUND OF CASE STUDY AND THE MAIN EMPIRICAL EVIDENCE}

In the early 1980s, John F. Fithchen III reported common problems of ventilation through the ages. He wrote that 'problems of illumination, warming and smoke elimination in cold climates, cooling and air circulation in hot climates, of humidification, and maintaining the integrity and longevity of the structure itself were vitally affected by ventilation' [4]. Almost all of those problems were also valid for the historic hospitals of Anatolia. Yet, few scholars either today or in the past have been sufficiently interested to record the ventilation and illumination practices of the historic buildings of Anatolia, let alone of the hospitals [2, 3, 5-8]. Hence, the notes on those practices applied in the case of Anatolian Seljuk and Ottoman period hospitals, and presented in the following pages, are mostly the result of the author's field works from 2010 to 2014 or of historic records including endowment deeds and texts on previous interventions. Although the hospitals have undergone many alterations over the centuries, resulting in the destruction of some details, ventilation and illumination could still be identified to some extent.

\subsection{Illumination systems in historic hospitals of Anatolia}

In historic hospitals, both natural and artificial illumination elements were observable. Sun was the primary illumination source in the daytime. Natural illumination was provided by ceiling holes/vents/windows with varying dimensions, forms and numbers and by windows at different levels during the day. According to archival sources, such as the waqf deeds of the hospitals, it is understood that oil lamps, candles, torches and similar artificial illumination sources were used during the nights and early mornings. For instance, there are small niches in the walls of the rooms in historic hospitals, which might have been designed to hold candlesticks or oil lamps. Such details are also observable in historic Turkish baths. Bathing scenes in miniatures and research studies clearly exhibit hung oil lamps, or niches for candlesticks recessed in the walls above the basins, or a form of cantilevered projections [7]. As an instance, in Divriği Melike Turan Hospital, the cantilevered projection at the end of the stairs towards the first floor was interpreted as being used for artificial lighting elements [3, 9]. Similarly, in the bath section of Atik Valide Hospital, in the walls of the caldarium section above the basins, there are niches that might have been used for artificial lighting (Fig. 1). Although there are
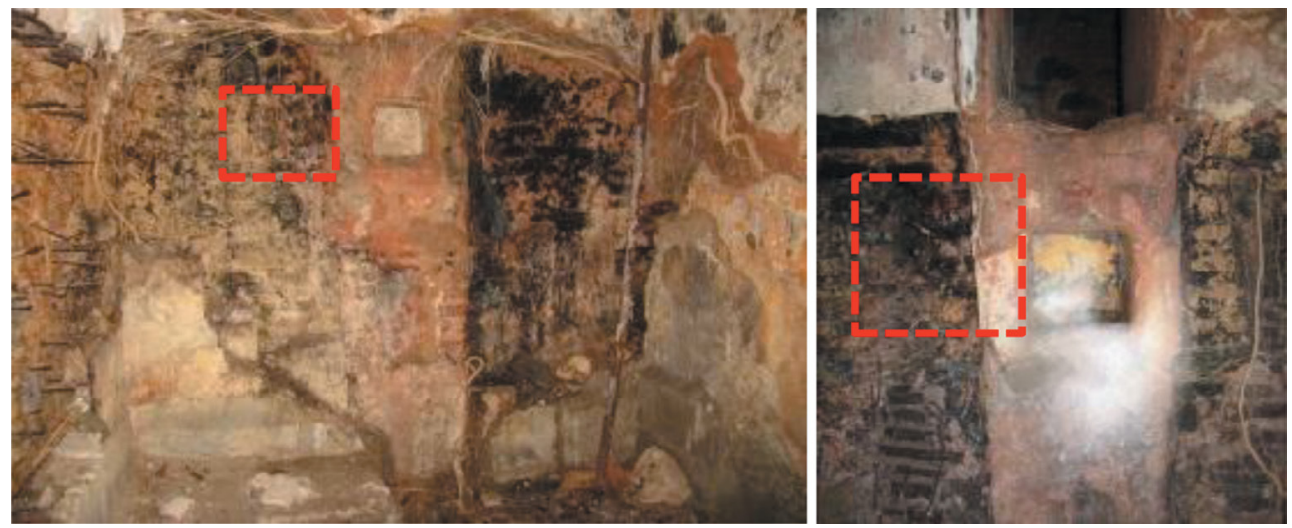

Figure 1: Wall niches above the basins in the caldarium of the bath section in Atik Valide Hospital (photo: author's archives, 2011). 
no traces in the historic hospitals, in some other historic buildings, such as Doğu Beyazit, İshak Pasa Place, located on the tops of wall niches designed for the placement of candles or candlesticks, there are circular ventilation holes to emit the smoke (Fig. 2) [3]. In the baths and toilets of the hospitals, specially shaped ceiling openings, made of terracotta pipes with glass tops arranged above the brick bonds of the domes/vaults, called oculi (light holes), were another illumination detail, reminiscent of the light-collecting glass application of today's technology (Fig. 3) [2, 10].

In the case study of Ottoman period hospitals, narrow, long windows with frequent intervals, expanded to the whole facade, provided illumination of the whole interior space into the

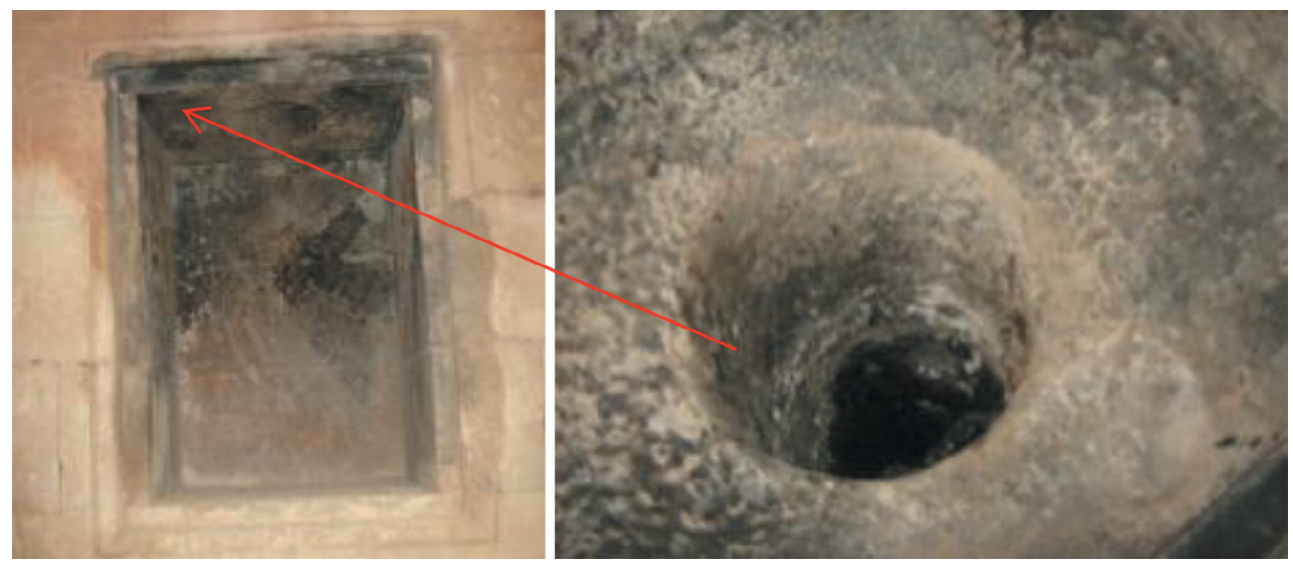

Figure 2: A niche (left) and its ventilation hole (right) on one of the walls in Ishak Pasa Palace, used for candles (photo: author's archives, 2011).
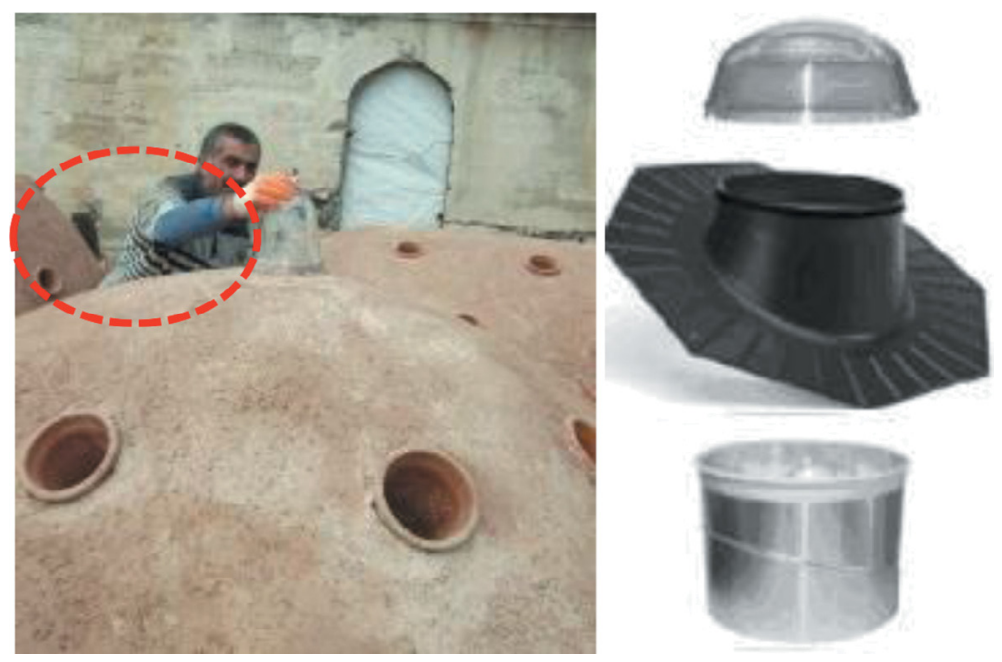

Figure 3: Oculi (light holes) on the vaults/domes of the bath section in Süleymaniye Hospital (left) (photo: archives of Fatma Usluer, 2011) and the light-collecting glass application of today's technology (right) [10]. 


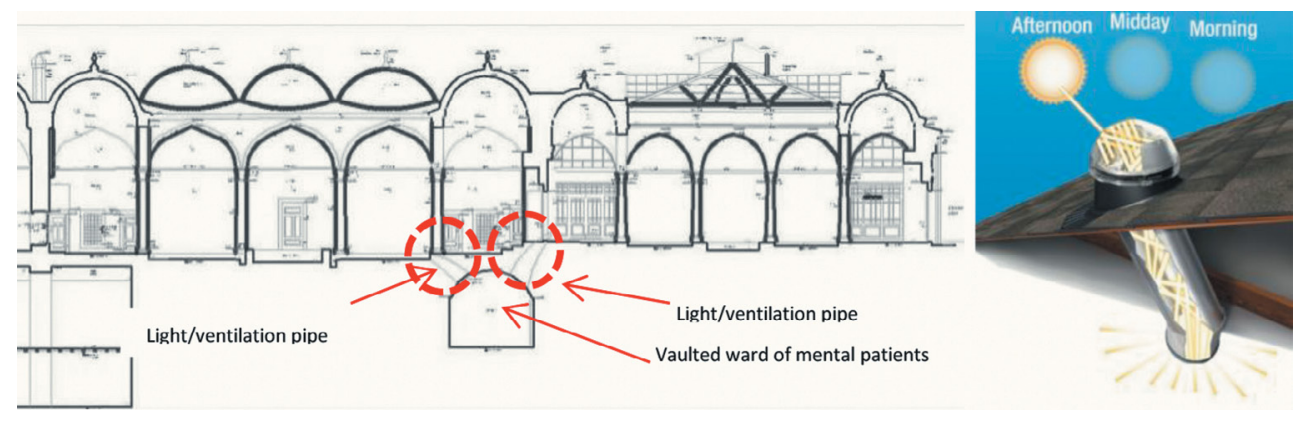

Figure 4: Süleymaniye Hospital light/ventilation pipe detail on the vault of the mental patients' ward (left) (source: drawing archives of Directorate General of Foundations, 2016) and contemporary light pipe detail (right) [10].

deepest areas. In addition, there are windows located at different levels of the facade in order to increase the amount of natural lighting.

\subsection{Ventilation systems in historic hospitals of Anatolia}

In the Ottoman period, hospitals, fireplaces and their chimneys were used not only to heat the space on winter days but also to ventilate the space on hot summer days. Thus, besides doors and windows, the fireplace chimneys were alternative ventilation elements $[2,3,5,11]$. In the Seljuk period, however, as there were no chimneys and fireplaces, the ceiling holes of the vaults, as well as doors and windows, were the primary means of ventilation and illumination [5]. For instance, in Kayseri Gevher Nesibe Hospital and Madrasah and in Amasya, Anber Bin Abdullah Hospital, there are ceiling holes located at certain intervals on the vaults of the rooms. Considering their small dimensions, small splayed openings (dimensions: $0.30 \mathrm{~m} \times 0.95 \mathrm{~m}$ ) on the walls of Amasya Anber Bin Abdullah Hospital were also used for ventilation [12]. In hospitals, which have separate baths, tüteklik/vertical ventilation pipes located inside the walls and lying along the hypocaust section up to the roof level provided for the emission of excess smoke. In Edirne Beyazıt II Hospital, the central space and the summer rooms opening onto it were ventilated by means of a ventilation lantern in the middle of the dome covering the central space. In the winter rooms, on the other hand, the fireplace chimneys, as well as windows, were the main ventilation elements. In Süleymaniye Hospital, another ventilation/illumination detail was observable in the mental patients' wards. The problem of ventilation/illumination of this vaulted room, located on the basement floor, was solved by six hidden splayed windows, with dimensions of $0.47 \mathrm{~m} \times 0.55 \mathrm{~m}$, and small vents (dimensions: $0.41 \mathrm{~m} \times 0.17 \mathrm{~m}$ ) opening onto the courtyard [3]. Those small vents can be interpreted as functioning as the light pipes of today's technology, used to allow the light to penetrate and thus illuminate the spaces that lack sunlight [10] (Fig. 4). Open courtyards, semi-open porticos, courtyard fountains, greenery and vegetation were the other ventilation and cooling means in historic hospitals (Tables 1 and 2).

\section{ANALYSIS OF KEY POINTS AND IMPLICATIONS FROM THE EMPIRICAL CASE}

Tables 3 and 4, compiled mostly from in situ observations and historic analysis, list the possible ventilation and illumination practices of the hospitals and therefore allow some conclusions to be drawn about those practices; these are briefly explained below. 


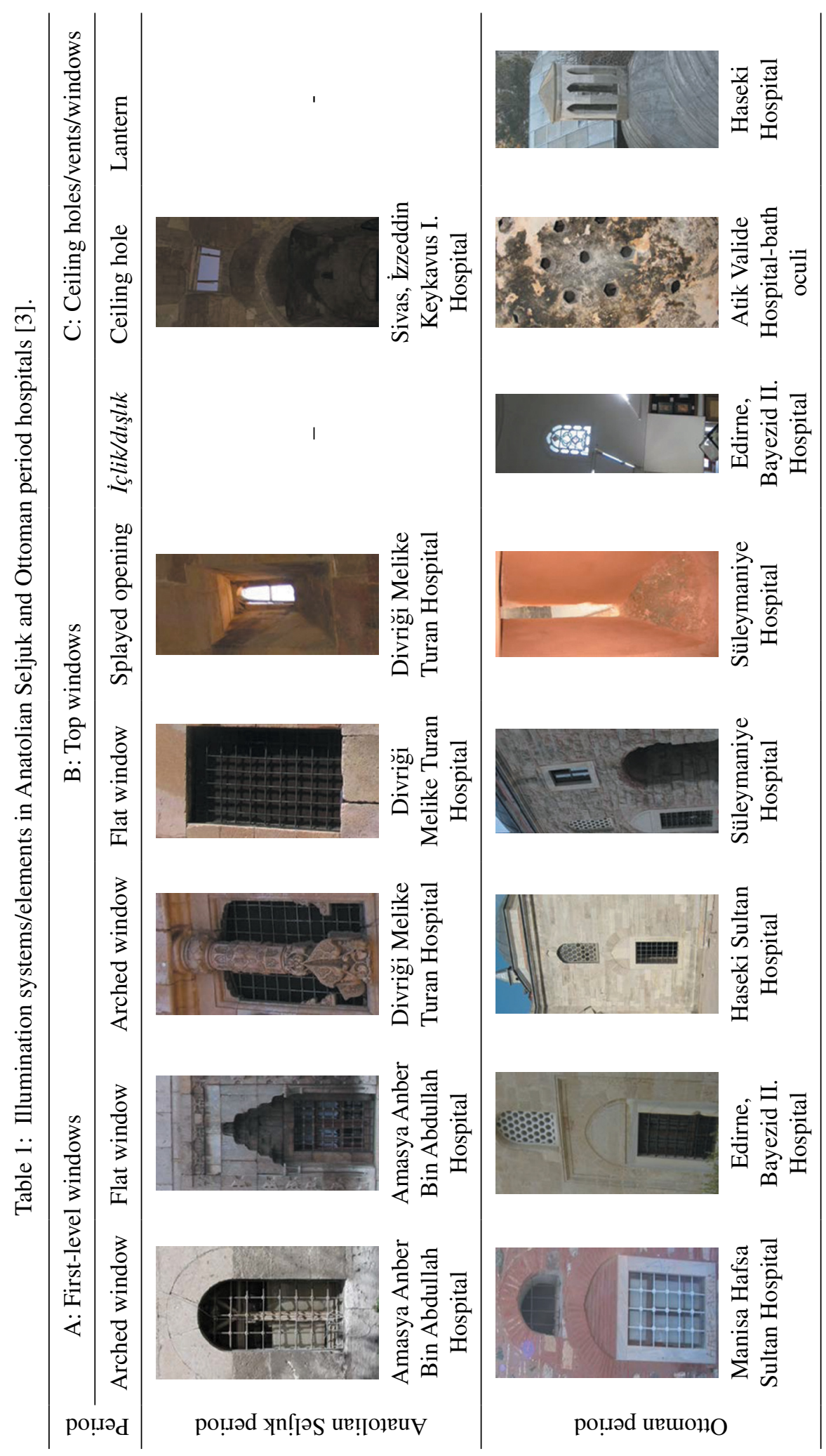




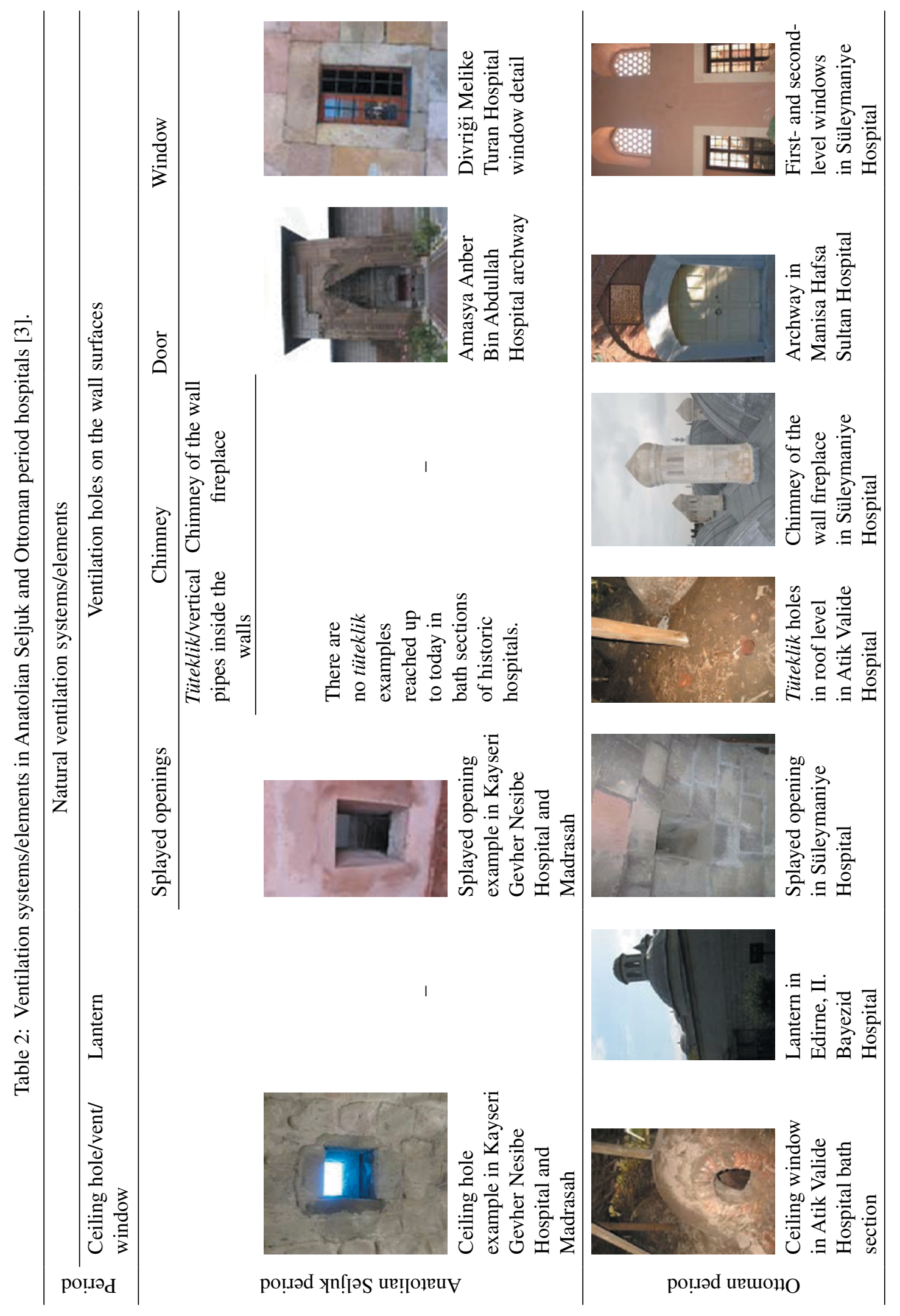


- Ventilation in Anatolian Seljuk hospitals was mostly provided by ceiling holes and by windows and doors in varying dimensions and shapes. In the Ottoman period, lanterns and fireplace chimneys were added, as well as doors and windows. For instance, the ceiling holes/vents of the Seljuk period hospitals, such as in Amasya Anber Bin Abdullah Hospital (radius of the vent $\approx 0.60 \mathrm{~m}$ ), in Kayseri Gevher Nesibe Hospital (base area of the vents $\approx 0.40 \times 0.30 \mathrm{~m}, \approx 0.30 \times 0.20 \mathrm{~m}, \approx 0.40 \times 0.40 \mathrm{~m}$ ) and in Divriği Melike Turan Hospital (radius of the vent $\approx 0.90 \mathrm{~m}$ ), have been replaced with the polygonal roof lanterns of the Ottoman period, as in Haseki Hospital (base area of lantern $\approx 1.50 \times 1.50 \mathrm{~m}$ and height $\approx 1.90 \mathrm{~m}$ ) and in Süleymaniye Hospital above the baker's room (one side $\approx 0.45 \mathrm{~m}$ and height $\approx 1.52 \mathrm{~m}$ ). Tütekliks (vertical ventilation pipes) were used during both periods in the bath sections of the hospitals. In addition to wall fireplaces and their roof extensions, such as chimneys in the Ottoman period hospitals, an open courtyard plan layout, semi-open spaces, such as iwans and waiting lounges, colonnaded porticos, pools and vegetation in the courtyards were the other details affecting the ventilation quality of the spaces in both periods. It is understood that technological developments in ventilation systems of historic hospitals such as an increase in the number and dimensions of window-door openings in spaces, and the addition of ventilation/illumination lanterns and fireplace chimneys, instead of ceiling holes/vents, were directly related to the developments in illumination and heating systems [3].

- The sun was the primary illumination source in the hospitals. After sunset, either the oil lamp or candle was used, in addition to the fire in the fireplaces in winter times. The niches on the wall surfaces of the hospitals and the endowment deeds prove the use of those indirect illumination sources. In the hospitals' baths and toilets, where privacy conditions were provided for, oculi (light holes) and small window dimensions were applied for the illumination of the spaces. In Anatolian Seljuk period hospitals, the small dimensions and limited numbers of windows resulted in dimly lit spaces, whereas in Ottoman period hospitals, with the increase in the number and dimensions of wall openings, more well-lit spaces were observable. A special space used for the preparation of medicines was evident in Kayseri Gevher Nesibe Sultan Hospital. This space, with the minimum illumination just a door opening - is interpreted as being used for the preparation of medicines sensitive to sunlight [13]. In addition, again in Kayseri Gevher Nesibe Sultan Hospital, in spaces that are thought to have been used for surgery operations, there are only ceiling openings and doors for ventilation and illumination purposes. This arrangement could mean that artificial illumination elements were used during the operations and/or all the operations were conducted during the daytime [3].

As a result of the analysis of the detection of ventilation and illumination systems/elements in the case study hospitals of each period, according to their reliability degrees, it is understood that most of those systems/elements have been determined precisely because of their existence in the building (85\% of ventilation systems and $49 \%$ of illumination systems) or their existence and traces could be identified from the historic and local service systems observed in the region ( $40 \%$ of illumination systems). The existence and traces of only $1 \%$ of ventilation and illumination systems/elements in historic hospitals could be identified from the other examples in the mosque complex, while the existence of $12 \%$ could be identified from written, oral or visual sources (Table 3 ). 
Table 3: Results obtained from the analyses of ventilation and illumination systems in Anatolian Seljuk and Ottoman period hospitals.

\begin{tabular}{|c|c|c|c|c|c|}
\hline \multirow[b]{2}{*}{ 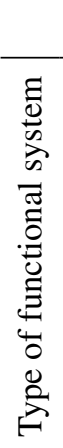 } & \multirow[b]{2}{*}{$\begin{array}{l}\text { Functional system/ } \\
\text { element }\end{array}$} & \multicolumn{4}{|c|}{ Analyses of functional systems according to their reliability } \\
\hline & & $\begin{array}{l}\text { Those } \\
\text { known } \\
\text { precisely } \\
\text { because } \\
\text { of their } \\
\text { existence in } \\
\text { the building } \\
\text { - }\end{array}$ & $\begin{array}{l}\text { Their } \\
\text { existence and } \\
\text { traces could } \\
\text { be identified } \\
\text { from other } \\
\text { examples in } \\
\text { the mosque } \\
\text { complex }\end{array}$ & $\begin{array}{l}\text { Their } \\
\text { existence } \\
\text { could be } \\
\text { identified } \\
\text { from } \\
\text { written, oral } \\
\text { or visual } \\
\text { sources }\end{array}$ & $\begin{array}{l}\text { Their existence } \\
\text { and traces could } \\
\text { be identified } \\
\text { from the historic } \\
\text { and local } \\
\text { service systems } \\
\text { observed in the } \\
\text { region }\end{array}$ \\
\hline \multirow{7}{*}{ 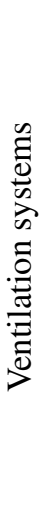 } & Ceiling holes/vents & - $(5)$ & 0 & 0 & 0 \\
\hline & Roof lantern & $\mathbf{\square}(4)$ & 0 & 0 & 0 \\
\hline & $\begin{array}{l}\text { Splayed windows/ } \\
\text { openings }\end{array}$ & $\mathbf{\square}(5)$ & 0 & 0 & 0 \\
\hline & $\begin{array}{l}\text { Tüteklik } \\
\text { (ventilation pipes) }\end{array}$ & $\mathbf{\square}(4)$ & 0 & $\diamond(2)$ & 0 \\
\hline & Chimneys & $\mathbf{\square}(5)$ & $\Delta(1)$ & $\diamond(2)$ & 0 \\
\hline & Doors & - $(11)$ & 0 & $\diamond(1)$ & 0 \\
\hline & Windows & - $(10)$ & 0 & $\diamond(2)$ & 0 \\
\hline \multicolumn{2}{|c|}{ Sub-total } & $44(85 \%)$ & $1(2 \%)$ & $7(13 \%)$ & $0(0 \%)$ \\
\hline \multirow{9}{*}{ 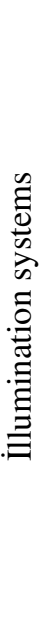 } & Doors & a (11) & 0 & $\diamond(1)$ & 0 \\
\hline & Windows & - (10) & 0 & $\diamond(2)$ & 0 \\
\hline & $\begin{array}{l}\text { Ceiling holes/ } \\
\text { vents/windows }\end{array}$ & $\mathbf{\square}(5)$ & 0 & 0 & 0 \\
\hline & Oculi (light holes) & $\mathbf{\square}(4)$ & 0 & 0 & - (2) \\
\hline & Roof lantern & $\mathbf{\square}(4)$ & 0 & 0 & 0 \\
\hline & $\begin{array}{l}\text { İllumination } \\
\text { openings }\end{array}$ & $\mathbf{a}(5)$ & 0 & 0 & 0 \\
\hline & Torch & 0 & 0 & 0 & - (12) \\
\hline & Oil lamp & 0 & 0 & $\bullet(3)$ & • (9) \\
\hline & Candle/candlestick & 0 & 0 & $\diamond(3)$ & • (9) \\
\hline \multicolumn{2}{|c|}{ Sub-total } & $39(49 \%)$ & $0(0 \%)$ & $9(11 \%)$ & $32(40 \%)$ \\
\hline \multicolumn{2}{|c|}{ Total } & $83(63 \%)$ & $1(1 \%)$ & $16(12 \%)$ & $(24 \%)$ \\
\hline
\end{tabular}




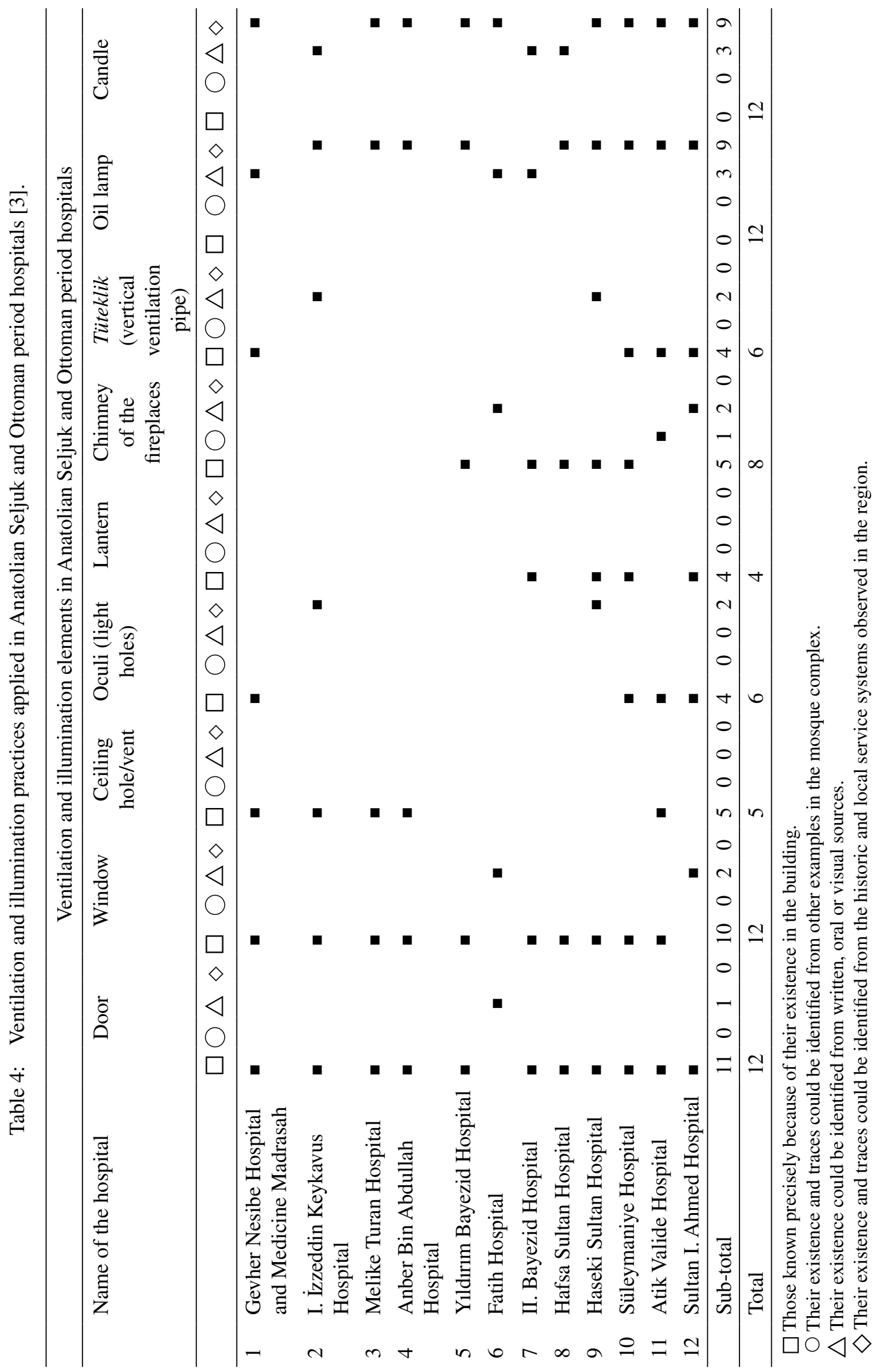




\section{ASSESSMENT OF CONSERVATION MEASURES FOR VENTILATION AND İLLUMINATION SYSTEMS/ELEMENTS}

A thorough investigation of historic conservation studies and project preparation works conducted by the Directorate General of Foundations and the Ministry of Culture and Tourism - as the chief governmental institutions responsible for conservation studies in Turkey - has clearly shown that rather few conservation measures are defined for the conservation of original functional systems in historic buildings. In addition, both survey and restoration project preparation specifications and also specifications for the implementation of restoration works lack detailed conservation measures and definitions in relation to possible/original functional systems. The Regulations on Energy Performance in Buildings dated 5 December 2008, number 27075, state that [14]:

The Regulations contain all business and process related to applications and precautions for the increase in energy efficiency in buildings registered as cultural heritage to be preserved without affecting their exterior surface and character defining features, in the view of the Ministry of Culture and Tourism.

Yet, those aforementioned regulations include only general suggestions instead of separate and special applications to be developed for historic buildings. In addition, the 1983 Cultural and Natural Heritage Conservation Act (no: 2863), Article 8, states that 'Conservation Councils shall identify the conservation site of the cultural and natural property to be protected that has been registered according to article seven, and make a decision on whether or not to build and install in this area' [15]. However, detailed mechanical and/or functional system projects have not been submitted to Conservation Councils; instead, restoration projects have been founded without enough critical review. Furthermore, Conservation Councils do not include experts on the analysis and investigation of historic functional systems, let alone on their conservation measures. Upon investigation of the 'Technical Specification on Survey, Restitution, Restoration Projects on Single Building Scale', it is understood that all the duties related to electrical, mechanical and heating systems are entirely designed for contemporary technologies, with no suggestions for either their possible adjustments and applications for historic buildings or the detection and preservation of original systems [16]. Thus, all those regulations, laws and specifications show that new arrangements are necessary for the detection and preservation of original functional systems and for their adjustment to the new technologies. Open courtyards with colonnaded porticos, splayed windows, wooden window shutters, high ceilings, ceiling holes, earthen roofs, ceiling windows and such construction details applied in historic hospitals are important passive survivability means required for the longevity of the buildings. Thus, it is important to increase the awareness of the relevant governmental bodies, university departments and non-governmental organizations in respect of the preservation of the aforementioned details. Hence, primary efforts and measures for the detection and conservation of ventilation and illumination systems/elements in historic hospitals have been determined below:

- In Seljuk period hospitals, on the vaults/rooftops of rooms that have no ventilation opening, except for doors today, possible ceiling openings originally used/designed for ventilation but destroyed in due course should be investigated.

- In bath sections of historic hospitals, research rasps are necessary on the wall surfaces in order to protect the original tuteklik/vertical ventilation pipes inside the walls and in order to determine the possible niches and projections closed today that might have been used for holding artificial illumination elements such as candles, candlesticks and oil lamps. It 
is also necessary to conduct an archival and historical literature survey to determine the original form and number of ceiling openings in the domes/vaults of bath sections.

- In some Ottoman period hospitals, because of the destruction of wall fireplaces, their roof extensions cannot perform their ventilation function as chimneys. In addition, since the windows are closed most of the time, today ventilation inside the rooms is provided by mechanical means, such as air conditioners and ventilation units installed on the exteriors walls. Therefore reopening those fireplaces and their roof chimneys is important for natural ventilation.

- In hospitals in which original illumination/ventilation system details are still protected, these should be preserved for future generations.

\section{CONCLUSIONS}

This study reveals a distinct perspective in architecture: the identification and analysis of the ventilation and illumination practices in Anatolian Seljuk and Ottoman period hospitals, previously unidentified and little explored. Hence, the study was an attempt to show that not only the building itself, but also the architectural details and different functional system practices, such as ventilation and illumination in a hospital, could and did play a significant role in both the longevity of the building and the preservation of healthy conditions for the users of those buildings. Those systems did not emerge untouched and unaltered - in some cases they were totally destroyed - yet, in the historic hospitals of Anatolia, those systems had often been the main concerns, which affected the heating, cooking and other daily practices of the time and region. The study showed that sometimes a hole in the ceiling or on the wall, or a hole lying along the wall, and sometimes indirect illumination sources, such as candles and oil lamps, as well as architectural details and specially planned layouts, played an important role in the ventilation and illumination of the spaces in historic hospitals.

\section{ACKNOWLEDGEMENT}

I am grateful to Professor Zühal Özcan, the advisor to my dissertation studies, of which this paper is a part. In addition, Professors M. Can Hersek and Z. Gediz Urak deserve special thanks for all their helpful advice and directions during my $\mathrm{PhD}$ studies.

\section{REFERENCES}

[1] Dişli, G., Planning of functional spaces in Ottoman Period hospitals (darüşşifa) of Anatolia. Al-Masaq: Journal of the Medieval Mediterranean, 27(3), pp. 253-276, here pp. 253-254, 2015.

[2] Disli, G., Sustainability of historic building systems: Anatolian Seljuk and Ottoman hospitals. APT Bulletin: Journal of Preservation Technology, 45(4), pp. 45-51, here pp. 45, 47, 2014.

[3] Disli, G., Anadolu Selçuklu ve Osmanlı Darüsşsifalarında Işslevsel Sistemlerin ve Koruma Ölçütlerinin Irdelenmesi. PhD Thesis, Gazi University: Ankara, here pp. 1, 87-108, 2014 (in Turkish).

[4] Fitchen, J. F. III., The problem of ventilation through the ages. Technology and Culture, 22(3), pp. 485-511, here p. 511, 1981. DOI: $10.2307 / 3104387$.

[5] Dişli, G. \& Özcan, Z., An evaluation of heating technology in Anatolian Seljuk Period hospitals (darüşşifa). Metu Journal of Faculty of Architecture, 33(2), pp. 1883-200, 2016. 
[6] Oğuz, G.P. \& Işık, N., Tarihi yapılardaki doğal ve yapay aydınlatma uygulamaları. II. Aydinlatma Sempozyumu, pp. 1-5, 2003.

[7] Önge, Y., Eski Türk Hamamlarında Aydınlatma. Vakıflar Dergisi, 12, pp. 121-136, 1978.

[8] Doğan, T., Osmanlı cami mimarisinde aydınlatma düzenleri açısından gelişim (XIV.-XVII yüzyıl). YYU Journal of Education Faculty, 10(1), pp. 295-320, 2013.

[9] Sakaoğlu, N., Türk Anadolu'da Mengücekoğulları, Yapı Kredi Yayınları: Istanbul, pp. 239-385, 2005.

[10] Görgülü, S., Kocabey, S., Yüksek, İ. \& Dursun, B., Enerji Verimliliği Kapsamında Yapılarda Doğal Aydınlatma Yöntemleri: Kırklareli Örneği. Uluslararası II. Trakya Bölgesi Kalkınma - Girişsimcilik Sempozyumu, pp. 97-111, here pp. 101-102, 2010.

[11] Özcan, Z., \& Dişli, G., Refrigeration technology in Anatolian Seljuk and Ottoman Period hospitals. Gazi University Journal of Science (GUJ Sci), 27(3), pp. 1015-1021, 2014.

[12] Bakır, B. \& Başağaoğlu, İ., Amasya Anber Bin Abdullah Darüşşifası. Amasya Uluslararası Anadolu-Türk Darüşşifaları ve Sabuncuoğlu Kongresi, pp. 35-46, 2008.

[13] Köker, A.H., Gıyasiye ve Şifaiye Yapısının Mimarisi. Selçuklular Devrinde Kültür ve Medeniyet, Gevher Nesibe Sultan Adına Düzenlenen Selçuklu Gevher Nesibe Sultan Tip Fakültesi Kongresi, pp. 17-30, 102-103, 1991.

[14] Enerji ve Tabbi Kaynaklar Bakanlığı, Binalarda Enerji Performansı Yönetmeliği, Resmi Gazete Tarihi: 5.12.2008 ve sayıs1: 27075, available at www.enerji.gov.tr (accessed 26 October 2016).

[15] Kültür ve Turizm Bakanlığı, 2863 sayılı Kültür ve Tabiat Varlıklarını Koruma Kanunu, 8. Madde, Resmi Gazete Tarihi: 21.7.1983, available at www.kulturturizm.gov.tr (accessed 12 October 2016).

[16] Kültür ve Turizm Bakanlı̆̆ı, Tek Yapı Ölçeğinde Rölöve, Restitüsyon ve Restorasyon Projeleri Teknik Şartnamesi, Madde 10.2 ve Madde 10.3, available at www.kulturturizm. gov.tr (accessed 18 October 2016). 